Volume 9, No.3, May - June 2020

International Journal of Advanced Trends in Computer Science and Engineering

Available Online at http://www.warse.org/IJATCSE/static/pdf/file/ijatcse19932020.pdf

https://doi.org/10.30534/ijatcse/2020/19932020

\title{
Designing Effective E-Learning System in Kanisius School with Zachman Framework
}

\author{
Albertus Henny Setyawan ${ }^{1}$, Rachmawan Adwitia Atmaja ${ }^{2}$, Gunawan Wang ${ }^{3}$, Nilo Legowo ${ }^{4}$ \\ ${ }^{1,2,3,4}$ Information Systems Management Department, BINUS Graduate Program Master of Information Systems, \\ Bina Nusantara University, West Jakarta 11480, Indonesia. \\ 1 albertus.setyawan@binus.ac.id, ${ }^{2}$ rachmawan.atmaja@binus.ac.id, ${ }^{3}$ gwang@binus.edu, ${ }^{4}$ nlegowo@binus.edu
}

\begin{abstract}
In facing the current technological developments, Kanisius School must continue to develop and dare to take steps to innovate in the process of education services. Therefore the school needs to create a framework, methods and management practices in managing IS/IT in the school. The design of the E-Learning system at Kanisius School uses the Enterprise Architecture approach with Zachman Framework which is a reference in developing IS/IT in an organization or company. Besides, Enterprise Architecture utilizes information and communication technology to support the organization's operational activities and enhance the ability of data integration between parts of the organization. For modeling using UML such as Use Case Diagram and Activity Diagram described using PowerDesigner software by SAP. The results of this study are a blueprint of E-learning systems in Kanisius School. This Blueprint can be used as a reference in the future for developing the E-Learning system at Kanisius School.
\end{abstract}

Keywords : E-Learning, Enterprise Architecture, Zachman Framework

\section{INTRODUCTION}

In March 2020 in Wuhan, China, COVID-19 pandemic started to spread and the vaccine had not been found until this article was written. The pandemic caused many countries in the world, including Indonesia, to employ lockdown policy and implement WFH (Work from Home). In Indonesia's capital city, Jakarta, the community is required not to leave the house for 14 days to reduce the spreading rate of COVID-19 virus. As a result, many aspects of the industry have experienced business process changes and some have suffered losses. One of them is Kanisius School. From the beginning, Kanisius School only accepts homogeneous (male) students. Through the digital transformation, the difficulty in finding homogeneous new students can be lesser because its wide reach is not limited to the Jakarta area alone.
The students are required to do SFH (Study from Home) and do distance learning / E-Learning with the teachers. Through E-Learning, students can learn and send assignments without having to come to school. This causes non-academic assistance to students becomes a challenge, face to face learning becomes virtual learning. Besides, student counseling which is usually done in the counseling guidance room turns into virtual counseling. In addition to being a challenge, it is a new idea to change the conventional learning system into E-Learning.

For sports subjects, physical activities were usually done together in the field with the teacher. Then, it is changed with the teacher provides theories and instructions in the virtual classroom via a video about how to do a particular activity and students do it themselves in their respective places, record their activities, and upload videos of their sports activities in a virtual classroom.

Although the school is aware of the opportunities of this digital transformation, they have difficulties in implementing Enterprise Architecture in existing business processes. The school needs to create a management framework, method and practice to regulate are / IT in the school. Enterprise Architecture (EA) is a reference in developing and developing information technology and systems in an organization or company. Besides, EA utilizes information and communication technology to support the organization's operational activities and enhance the ability of data integration between parts of the organization.

Kanisius School must continue to innovate and develop, dare to take steps to renew in the process of education services. Embracing the digital world is a goal for Kanisius school in order to survive during the development of information systems today.

\section{LITERATURE REVIEW}

\subsection{E-Learning}

E-Learning innovation can be defined as a form of technological or methodological learning that is considered new by potential users [1]. [2] also states that modern 
technology, that is the Internet, is no longer confined to the four walls of the classroom and it includes all types of learning that are supported electronically as well as teaching. E-Learning can also be defined as learning through the use of electronic devices, i.e. desktop/laptop computers, smartphones, CD / DVD players, etc. The growth of E-Learning is accredited for benefits such as labor, cost, flexibility, and convenience [3].

Some other definitions of E-Learning are: E-Learning refers to the use of computer network technology, especially through or through the internet, to provide information and instructions to individuals [4]. E-Learning includes a series of applications and processes, including online multimedia activities such as the web, SD-ROM, Internet video, TV, and radio. Students can use these materials to teach themselves [5]. E-Learning is a series of applications and processes, such as web-based learning, computer-based learning, virtual classrooms, and digital collaboration. This includes sending content via the internet, intranet/extranet (LAN / WAN), audio and video cassettes, electronic broadcasts and digital media satellite broadcasts, interactive TV, and CD-ROMs [6].

\subsection{Enterprise Architecture}

Definition of EA from Tamm and al. [7]: "EA is the definition and representation of high-level views about the company's business processes and IT systems, their interrelations, and the extent to which these processes and systems are shared by various parts of the company". EA applies architectural principles and practices to guide organizations through the changes in business, information, processes, and technology needed to carry out their strategies. Finally, there are descriptive and prescriptive definitions of EA, for example, the IS Research Center (CISR) at MIT defines EA as "organizing logic for business processes and IT capabilities that reflect the requirements of integration and standardization of the company's operating model" [8].

EA is used by many organizations especially for providing integrated business and SI / IT solutions for sustainability and competitiveness [9]. EA activities are carried out through a framework, which is a process of effectiveness and efficiency, arising from the elimination of tasks that do not add value and excessive, streamlining information flow, strategic placement of systems and business restructuring [10]. Business architecture defines a company from a business perspective, which includes the vision and mission of the business needed to guide its strategic and daily operations [11]. Basically, information architecture describes the structure of a company's logical and physical data assets as well as data management resources, which inform the application architecture [12].

\subsection{Zachman}

The Zachman Framework was first published in 1987 [13], then revised and extended in 1993 and 1999 respectively [14]. The Zachman Framework defines architecture as a set of relevant design artifacts or descriptive representations to describe an object so that it can be produced with requirements (quality) and maintained throughout its useful life (change). Zachman's framework has received wide acceptance from many organizations in all works of life [15].

\begin{tabular}{|c|c|c|c|c|c|c|}
\hline & $\begin{array}{l}\text { What } \\
\text { (Data) }\end{array}$ & $\begin{array}{c}\text { How } \\
\text { (Function) }\end{array}$ & $\begin{array}{l}\text { Where } \\
\text { (Locations) }\end{array}$ & $\begin{array}{c}\text { Who } \\
\text { (People) }\end{array}$ & $\begin{array}{l}\text { When } \\
\text { (Time) }\end{array}$ & $\begin{array}{c}\text { Why } \\
\text { (Motivation) }\end{array}$ \\
\hline $\begin{array}{c}\begin{array}{c}\text { Scope } \\
\text { \{contextual\} }\end{array} \\
\text { Planner }\end{array}$ & $\begin{array}{l}\text { List of things } \\
\text { important to the } \\
\text { business }\end{array}$ & $\begin{array}{c}\text { List of processes } \\
\text { that the business } \\
\text { performs }\end{array}$ & $\begin{array}{l}\text { List of locations in } \\
\text { which the } \\
\text { business } \\
\text { operatses }\end{array}$ & $\begin{array}{c}\text { List of } \\
\text { organizations } \\
\text { important to the } \\
\text { business }\end{array}$ & $\begin{array}{l}\text { List of events/ } \\
\text { cycles important } \\
\text { to the business }\end{array}$ & $\begin{array}{l}\text { List of business } \\
\text { goals/strategies }\end{array}$ \\
\hline $\begin{array}{l}\text { Enterprise Model } \\
\text { \{conceptual\} } \\
\text { Business Owner }\end{array}$ & $\begin{array}{l}\text { e.g. Semantic } \\
\text { Model }\end{array}$ & $\begin{array}{l}\text { e.g. Business } \\
\text { Process Model }\end{array}$ & $\begin{array}{l}\text { e.g. Business } \\
\text { Logistics System }\end{array}$ & $\begin{array}{l}\text { e.g. Workfow } \\
\text { Model }\end{array}$ & $\begin{array}{l}\text { e.g. Master } \\
\text { Schedule }\end{array}$ & $\begin{array}{l}\text { e.g. Business } \\
\text { Plan }\end{array}$ \\
\hline $\begin{array}{c}\begin{array}{c}\text { System Model } \\
\text { \{logical\} }\end{array} \\
\text { Designer }\end{array}$ & $\begin{array}{l}\text { e.g. Logical Data } \\
\text { Model }\end{array}$ & $\begin{array}{l}\text { e.g. Application } \\
\text { Architecture }\end{array}$ & $\begin{array}{l}\text { e.g. Distributed } \\
\text { System } \\
\text { Architecture }\end{array}$ & $\begin{array}{l}\text { e.g. Human } \\
\text { Interface } \\
\text { Architecture }\end{array}$ & $\begin{array}{l}\text { e.g. Process } \\
\text { Structure }\end{array}$ & $\begin{array}{l}\text { e.g. Business } \\
\text { Rule Model }\end{array}$ \\
\hline $\begin{array}{l}\text { Technology Model } \\
\{\text { \{hyysical\} } \\
\text { Implementer }\end{array}$ & $\begin{array}{l}\text { e.g. Physical Data } \\
\text { Model }\end{array}$ & $\begin{array}{l}\text { e.g. System } \\
\text { Design }\end{array}$ & $\begin{array}{l}\text { e.g. Technology } \\
\text { Architecture }\end{array}$ & $\begin{array}{l}\text { e.g. Presentation } \\
\text { Architecture }\end{array}$ & $\begin{array}{l}\text { e.g. Control } \\
\text { Structure }\end{array}$ & e.g. Rule Desigr \\
\hline $\begin{array}{l}\text { Detailed Representation } \\
\text { \{out-of-context\} } \\
\text { Subcontractor }\end{array}$ & $\begin{array}{l}\text { e.g. Data } \\
\text { Definition }\end{array}$ & e.g. Program & $\begin{array}{l}\text { e.g. Network } \\
\text { Architecture }\end{array}$ & $\begin{array}{l}\text { e.g. Security } \\
\text { Architecture }\end{array}$ & $\begin{array}{l}\text { e.g. Timing } \\
\text { Definition }\end{array}$ & $\begin{array}{l}\text { e.g. Rule } \\
\text { Definition }\end{array}$ \\
\hline Functioning System & e.g. Data & e.g. Function & e.g. Network & e.g. Organization & e.g. Schedule & e.g. Strategy \\
\hline
\end{tabular}

Figure 1: Zachman Framework

The broader view of EA includes not only the model used to describe objects in the current state but also in the future because they are influenced by business strategies and requirements as a consequence. Also, the practical purpose of the Zachman Framework for building models is not easily achieved in many organizations [16]. Zachman's framework builds on the premise that the only way to manage complex object changes is through the manipulation of representative rendering (models) of these objects [17]. This framework tries to categorize the types of models that a company might need, to describe them in context and relevance [18].

\section{RESEARCH METHODOLOGY}

This research uses a case study approach that focuses on the application of Enterprise Architecture as a reference in designing E-Learning at Kanisius School. Data collection methods used in this study are:

\subsection{Observation}

Observation: This method is done by observing the situation and activities directed at the Kanisius School in Jakarta as an object to get accurate information

\subsection{Literature Study}

Literature Study: Collecting data by searching and study books and journals related to this research.

The framework used is Zachman Framework with $3 \times 6$ matrix, which consists of:

1) Scope / Planner's View: sets context, background, and goals. 
2) Business Model / Owner's View: sets the conceptual model of the enterprise.

3) Information Systems Architectures: describes the system architecture created using the UML method, namely: Use Case and Activity Diagrams and how the information system architecture is developed. Information system architecture in this stage is defined to include data architecture and application architecture that will be used by organizations.

\section{RESULTS AND DISCUSSION}

After collecting the data, the mapping process is then carried out into the framework that is used and described one by one to produce the system design needed.

\subsection{Scope / Planner's View}

In this section, it is often referred to as contextual architecture which explains the process of Admission of New Students, E-Learning, Student Assessment, Payment of Payment Orders at the Kanisius School in general.

\subsubsection{What}

This column describes the data presented from the planner's point of view. From the analysis of these data consist of:

1) Student Data are the identity data of students who have registered.

2) Academic and Non-Academic Data are data that contains academic grades (results of tests, Midterm Evaluations, and Year-End Assessments), students' achievements, attitudes and violations from the homeroom teacher or counselor.

3) Financial Data are information regarding payment, including Payment Order, Base Payment, Late Payment Information.

4) Lost \& Found Data are data about lost and found goods submitted to the Facilities \& Infrastructure section.

5) Course Data are data about learning material, practice questions, and final exams.

6) Entrance Test Data are data on the requirements for the admission of new students.

7) Registration Form Data are the registration data of prospective new students.

\subsubsection{How (Process)}

This column explains the process of Accepting New Students, E-Learning, Student Assessment, Payment of Payment Orders at Kanisius School.

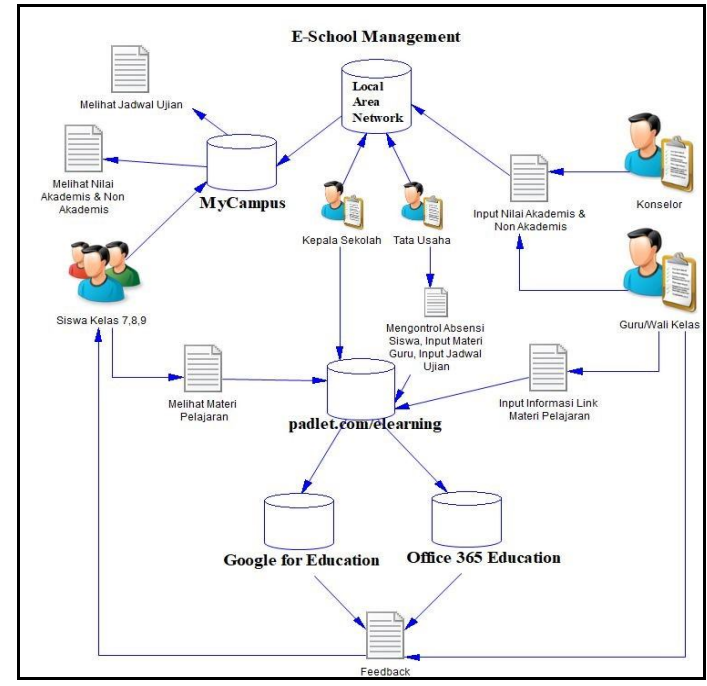

Figure 2: Learning and Assessment Process

\subsubsection{Where}

This column describes the location of the Kanisius School located at Menteng Raya Street 64, Central Jakarta

\subsubsection{Who}

This column describes human resources that play an important role in the process of Admission of New Students, E-Learning, Student Assessment, Payment of Payment Orders, namely:

1) The principal receives a report.

2) The administration manages student data.

3) IT staff performs maintenance on the server and helps teachers and students when experiencing problems in the IT field.

4) Teachers, homeroom teachers, and counselors provide material, grades, provide feedback and mentoring to students.

5) Prospective students register and pay the Payment Order.

\subsubsection{When}

This column discusses the schedule of online learning that is carried out at Kanisius School, from Monday to Friday, from 07.00 WIB to 13.30 WIB.

\subsubsection{Why (Motivation)}

This column describes the vision and mission of the Kanisius School as set out in the following statements:

1) The vision of the Kanisius School is "Excellent in providing educational services to prospective loyal future leaders".

2) The mission to be achieved by the Kanisius School is as follows:

a. Ensuring students to have an honest attitude, strive for God's greater glory and serve those in need.

b. Also has a brave attitude in leading, competence, conscience, compassion, and commitment. 


\subsection{Business Model/Owner's View}

For the owner, it will be explained about the proposed information system and how the system will run simply with the current IS / IT.

\subsubsection{What}

This column explains the concept of a simple business model that is limited to entities related to the New Student Admission process, E-Learning, Student Assessment, Payment of Payment Orders. These entities include:

1) Registration

2) Upload_Reg

3) Payment_Reg

4) Announcement_Reg

5) New students

6) Academic_Report

7) Academic_Non_Report

8) Upload_Course_Material

9) Upload_Course_Test

10) Payment_SPP

\subsubsection{How (Process)}

This column explains the new student registration process illustrated in Figure 4.

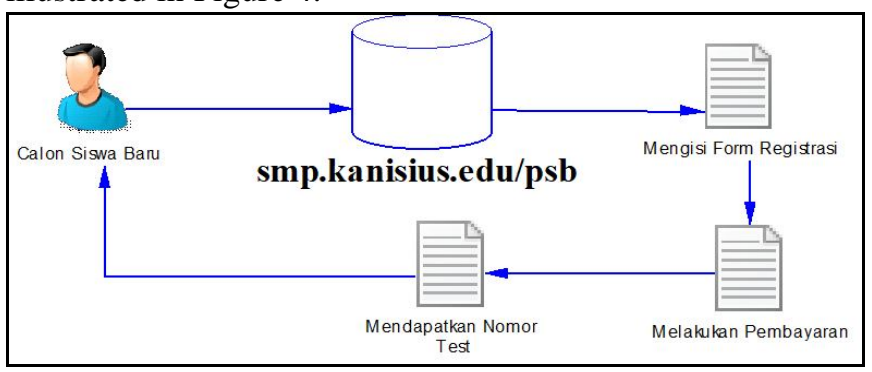

Figure 3: Registration Process

\subsubsection{Where (Location)}

This column explains the process of registering new students that can be done online without having to come to school and the application of E-Learning that allows friendships between students to be connected online.

\subsubsection{Who}

This column describes the human resources involved in the process of registering new students and the E-Learning process, namely: Principal, Teacher, Administrative Staff, and IT Staff.

\subsubsection{When}

This column explains the E-Learning material that can be accessed anytime and anywhere outside the daily routine schedule (Monday-Friday at 07.00 AM-13.30 PM).

\subsubsection{Why (Motivation)}

This column describes the objectives to be achieved related to the design of information systems created, namely:

1) Creating a good administration system in managing and storing data.
2) Building, operating, and implementing technology and applications in the field of IS / IT.

3) Being able to accept the number of prospective new students by reaching a wider area.

4) Providing more classroom learning options.

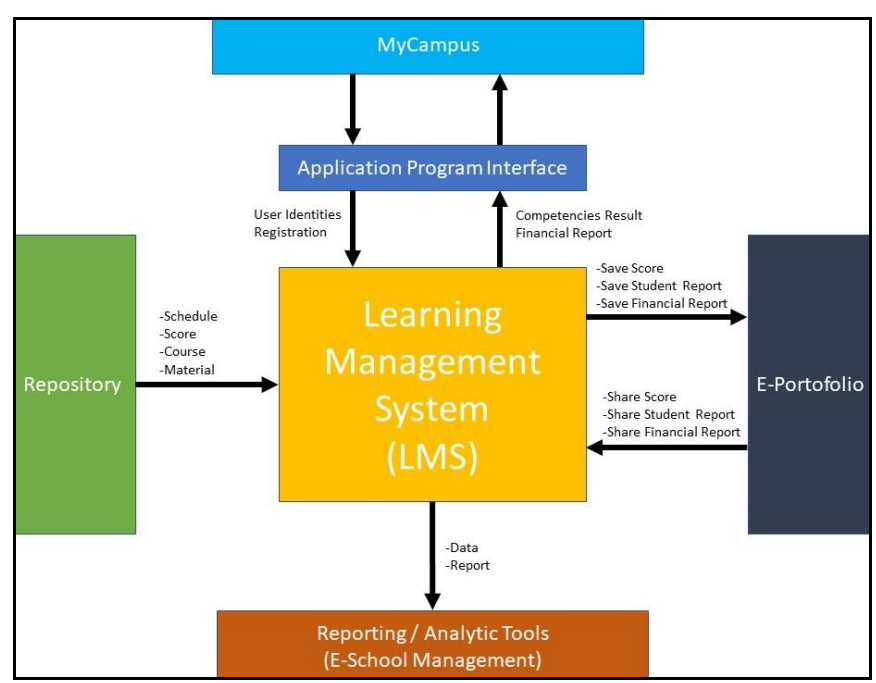

Figure 4: Proposed Business Architecture

\subsection{Information Systems Architecture}

At this phase, information system architecture will be designed and explained using the UML method. The following is an example of a use case diagram (Figure 5)and activity diagram of the E-Learning system for Kanisius School:

\subsubsection{Use Case Diagram}

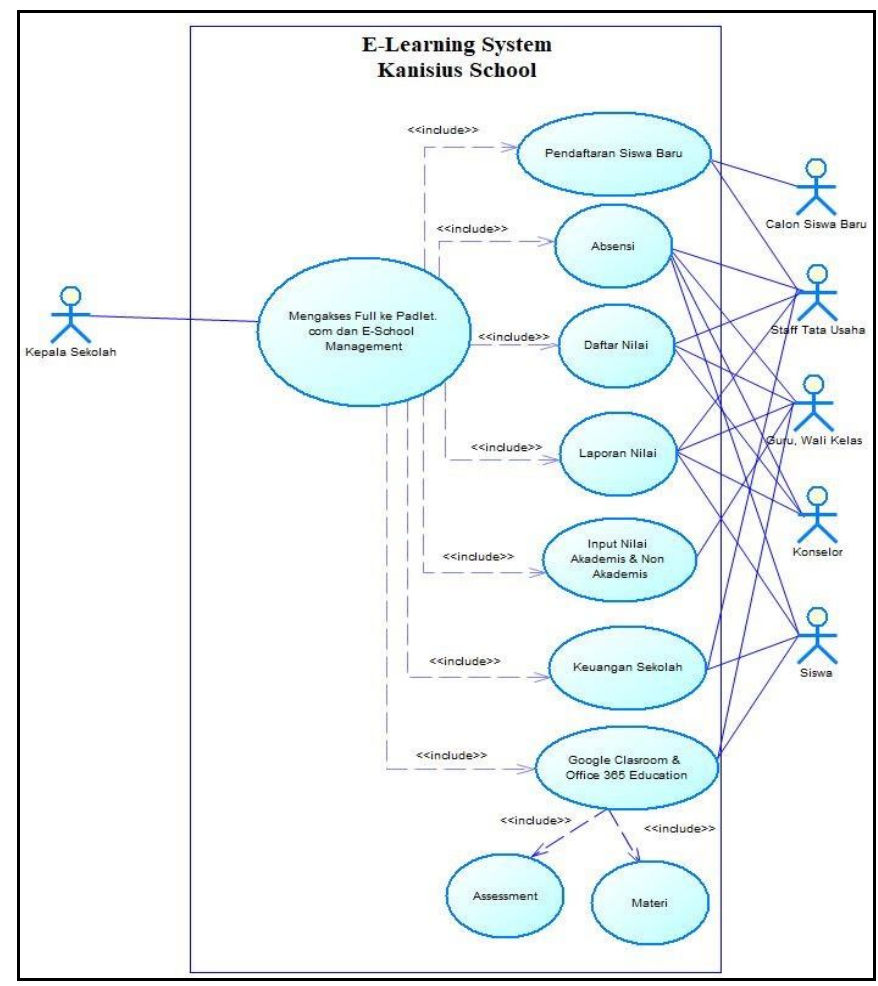

Figure 5: Use Case Diagram E-Learning System 


\subsubsection{Activity Diagram}

Figures 6 and 7 shows the enterprise model by describing business processes that include dependencies between process activities related to the information system E-Learning and New Student Admissions/Registration which will be built in the Kanisius School modeled using Activity Diagrams.

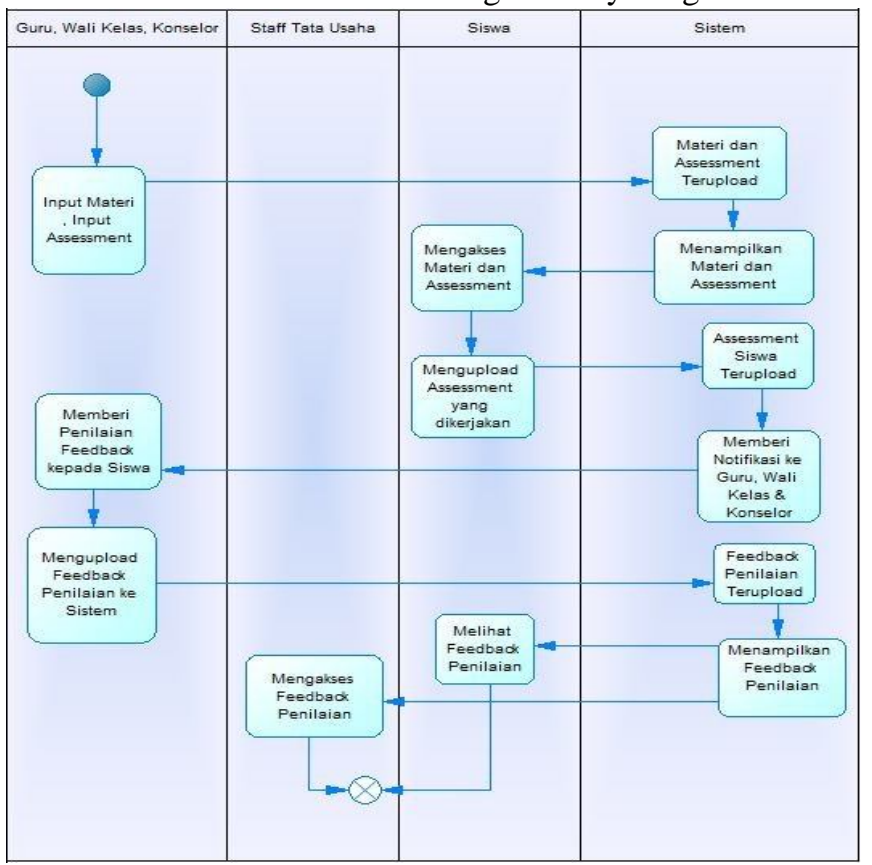

Figure 6: Activity Diagram E-Learning System

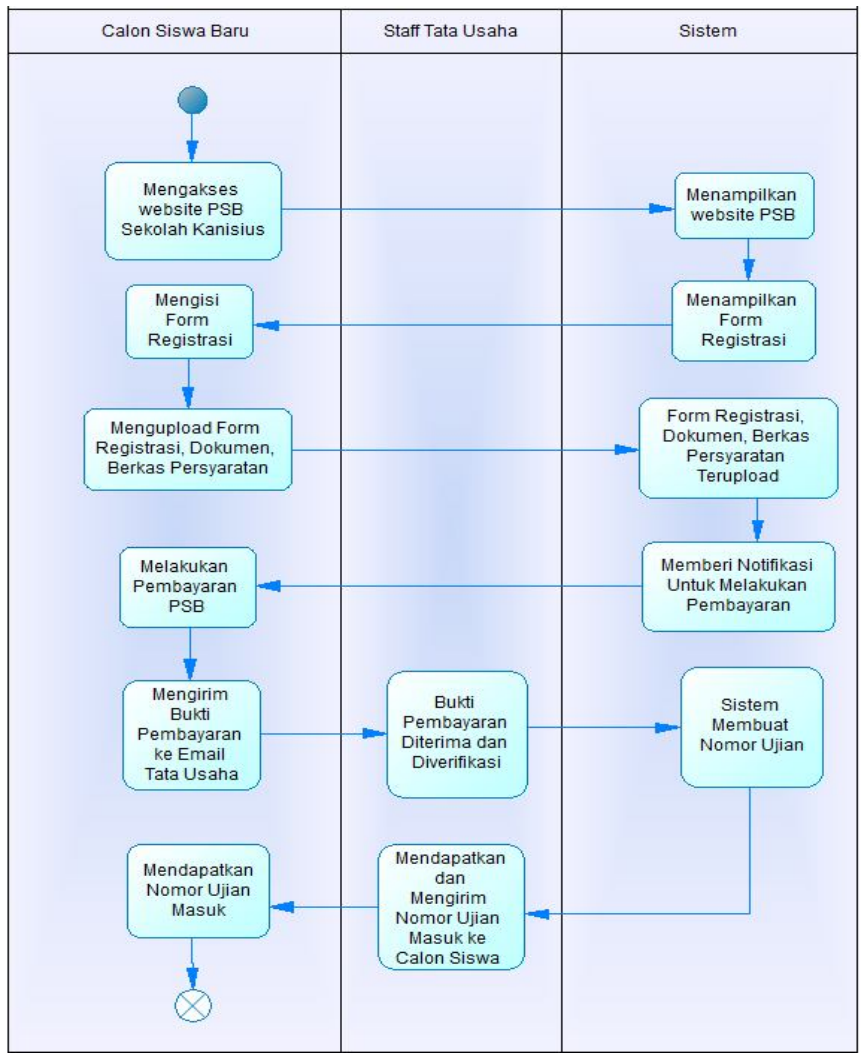

Figure 7: Activity Diagram Registration Process

\section{CONCLUSION}

Based on the results of research that has been done, the conclusions can be drawn as listed below:

1) This research resulted in the analysis and design of the E-Learning information system, Admission of New Students, and payment of Payment Orders at the Kanisius School using the Enterprise Architecture approach using of Zachman framework.

2) This analysis and design can be used as a basis for developing information systems for Kanisius School in going forward according to the vision and mission of the school.

3) Based on the results of the discussion, Enterprise Architecture approach in producing blueprints can model an effective, structured and integrated E-Learning Information System in the Kanisius School.

\section{REFERENCES}

1. Fischer, H. (2013), E-Learning im Lehralltag: Analyse der Adoption vonE-Learning-Innovationen in der Hochschullehre. Springer-Verlag. https://doi.org/10.1007/978-3-658-02182-5

2. Behera, SK. (2013), E- and M-Learning: A comparative study. International Journal on New Trends in Education and Their Implications 4(3): 65-78.

3. Ozkan S. and Koseler R. (2009), Multi-dimensional students' evaluation of e-learning systems in the higher education context: An empirical investigation. Computers \& Education 53(4): 1285-1296.

https://doi.org/10.1016/j.compedu.2009.06.011

4. Wang M, Ran W, Liao J, et al. (2010), A performance-oriented approach to e-learning in the workplace. Journal of Educational Technology \& Society 13(4): 167-179.

5. Hassenburg A. (2009), Distance education versus the traditional classroom. Berkeley Scientific Journal 13(1).

6. Nore'n CI. and Wiklund M. (2014), Learning paradigms in workplace e-learning research. Knowledge Management \& E-Learning 6(3): 299-315. https://doi.org/10.34105/j.kmel.2014.06.020

7. T. Tamm, P. B. Seddon, G. Shanks, and P. Reynolds, "How does enterprise architecture add value to organisations," Communications of the AIS, vol. 28, no. 1, pp. 141-168, 2011.

8. CISR, "Enterprise Architecture", MIT Center for IS Research, $2016 . \quad$ Available online:http://cisr.mit.edu/research/researchoverview/classic-topics/enterprise-architecture/ [Accessed: 26-Jun-2016].

9. Rouhani, B.D., Mahrin, M.N., Nikpay, F. and Rouhani, B.D. (2014), "Current issues on enterprise architecture implementation methodology", New Perspectives in Information Systems and Technologies, 
Vol. 2, Springer International Publishing, Berlin, pp. 239-246.

https://doi.org/10.1007/978-3-319-05948-8_23

10. Iyamu, T. (2015), Enterprise Architecture from Concept to Practice, Heidelberg Press, Victoria.

11. Simon, D., Fischbach, K. and Schoder, D. (2014), "Enterprise architecture management and its role in corporate strategic management", Information Systems and e-Business Management, Vol. 12 No. 1, pp. 5-42.

12. Fritscher, B., \& Pigneur, Y. (2015). Business IT alignment between business model and Enterprise architecture with a strategic perspective. International Journal of Information System Modeling and Design, 6(1), 1-23.

13. Zachman, J.A. (1987), "A framework for information systems architecture", IBM Systems Journal, Vol. 26 No. 3, pp. 276-292.

14. T. Iyamu, "The Factors Affecting Institutionalisation of Enterprise Architecture in the Organisation," 2009 IEEE Conference on Commerce and Enterprise Computing, Vienna, 2009, pp. 221-225.

https://doi.org/10.1109/CEC.2009.57

15. Benkamoun, N., ElMaraghy, W., Huyet, A.L. and Kouiss, K. (2014), “Architecture framework for manufacturing system design", Procedia CIRP, Vol. 17, pp. 88-93.

16. Löhe, J. and Legner, C. (2014), "Overcoming implementation challenges in enterprise architecture management: a design theory for architecture-driven IT management (ADRIMA)", Information Systems and e-Business Management, Vol. 12 No. 1, pp. 101-137. https://doi.org/10.1007/s10257-012-0211-y

17. Lapalme, J., Gerber, A., Van der Merwe, A., Zachman, J., Vries, D.M. and Hinkelmann, K. (2016), "Exploring the future of enterprise architecture: a Zachman perspective", Computers in Industry, Vol. 79, pp. 103-113. https://doi.org/10.1016/j.compind.2015.06.010

18. Nogueira, J.M., Romero, D., Espadas, J. and Molina, A. (2013), "Leveraging the Zachman framework implementation using action-research methodology a case study: aligning the enterprise architecture and the business goals", Enterprise Information Systems, Vol. 7 No. 1, pp. 100-132. https://doi.org/10.1080/17517575.2012.678387

19. Pujiyono, A. Y. M., Murahartawaty, M., \& Yunan, U. (2015). Perancangan Arsitektur Data Dan Aplikasi Pada Pt. Telehouse Engineering Menggunakan Framework Togaf Adm. eProceedings of Engineering, 2(2).

20. Buckl, S., Ernst, A. M., Matthes, F., Ramacher, R., \& Schweda, C. M. (2009, September). Using enterprise architecture management patterns to complement TOGAF. In 2009 IEEE International Enterprise Distributed Object Computing Conference (pp. 34-41). IEEE.
https://doi.org/10.1109/EDOC.2009.30

21. Suryadi, S., \& Andry, J. F. (2017, November). Perancangan Enterprise Architecture Mengunakan Togaf Architecture Development Method (Studi Kasus: Yakuza Gym Jakarta Barat). In Prosiding Seminar Nasional Teknoka (Vol. 2, pp. I29-I34). 